НАУКОВИЙ ВІСНИК

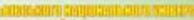

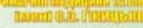

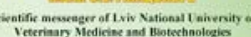

70

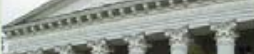

TIIII

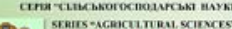

Toм 21 Nes 90

2019
Науковий вісник Львівського національного університету ветеринарної медицини та біотехнологій імені С.3. Гжицького. Серія: Сільськогосподарські науки

Scientific Messenger of Lviv National University of Veterinary Medicine and Biotechnologies. Series: Agricultural sciences

ISSN 2519-2698 print

https://nvlvet.com.ua/index.php/agriculture

doi: $10.32718 /$ nvlvet-a9007

\title{
Influence of feeding types of cows on the content of heavy metals in milk
}

\author{
O.M. Mamenko, S.V. Portiannik
}

Kharkiv State Zooveterinary Academy, Kharkiv, Ukraine

Article info

Received 29.01.2019

Received in revised form 05.03 .2019

Accepted 06.03.2019

Kharkov State Zooveterinary Academy. Academic Str., 1. Mala Danylovka, Dergachi district, Kharkov region, 62341 Ukraine. Tel.: +38-066-200-17-54 E-mail:Portynnyk@i.ua
Mamenko, O.M., \& Portiannik, S.V. (2019). Influence of feeding types of cows on the content of heavy metals in milk. Scientific Messenger of Lviv National University of Veterinary Medicine and Biotechnologies. Series: Agricultural sciences, 21(90), 37-48. doi: 10.32718/nvlvet-a9007

Around the industrial cities, the difficult environmental situation is due to the release of pollutants in the atmosphere that contain heavy metals, especially those that are dangerous to the environment, such as cadmium and lead. The increase in the accumulation of pollutant in soils of agricultural land also leads to the use of agrochemicals - pesticides and mineral fertilizers. Under such environmental conditions, it is necessary not only to grow crop production, but also to produce livestock products - milk. The production of environmentally safe, high-quality and competitive on the milk market requires the use of proven technological feeding and animal feeding methods. The selection of the optimal type of feeding of cows reduces the transition of heavy metals into dairy raw materials. In the experiment, it was found that the siln-root-type type of feeding had the smallest transition of $\mathrm{Cd}$ and $\mathrm{Pb}$ from feed rations into dairy raw materials, the transition factor of cadmium -0.24 , lead -0.25 . The most intense was the migration of Pb from the ration to milk from cows of the first control group with the silo-hinga-co-central type of feeding: the transition factor was 0.39 and $C d$ was 0.34. A similar situation was observed in cows of the first control groups with males and females feeding type, where the transition factor was $0.36 \mathrm{Cd}$ and $0.34 \mathrm{~Pb}$. The total supply of heavy metals with the diet for different types of feeding practically did not differ. The balancing of dietary rations with the specially developed mineral-vitamin premix "MP-A" contributed to the reduction of the transition of heavy metals $\mathrm{Cd}, \mathrm{Pb}, \mathrm{Cu}$ and $\mathrm{Zn}$ into milk, while the highest quality milk was obtained from cows with a haylage type of feeding. As a result of the experiment, it was possible to achieve a positive effect and reduce the content of heavy metals in milk of cows in all farms with different types of feeding animals for optimum quality and safety of milk, which met the requirements of the state standard, which convinces the transition factor, which was in the cows of the second experimental group on Cd 0,09 in animals with a sows-root-type type of feeding; 0.10 - silo-haylage; 0.12 - silage-hay type and 0.15 with silo-haylageconcentrate type, respectively; $\mathrm{Pb}-0.01$ in cows with a hill-and-hay type of feeding; 0.07 - silo-haylageconcentrate; 0.08 - silo-root crop and 0.09 with silo-hay type respectively; $\mathrm{Cu}-0.01$ in cows with silohaylage and silo-root-crop type of feeding; 0.02 with silo-haylage-concentrate and silo-hay type respectively; $\mathrm{Zn}-0.05$ in animals with males and haylings type of feeding; 0.06 - silo-haylage-concentrate; $0.08-$ silo-root crop and 0.010 with silo-hay type, respectively. In the third experimental group of cows, the average transition factor of heavy metals from milk to $\mathrm{Cd}, \mathrm{Pb}, \mathrm{Cu}$ and $\mathrm{Zn}$ was 0.04. The use of premix and biopreparation has reduced the transition of heavy metals from milk to an average of 1.5-4.3 times. Productivity of animals was on average in cows of the second and third experimental groups of 17-22 $\mathrm{kg}$ per day compared with the control group - $14 \mathrm{~kg}$. The content of $\mathrm{Cd}$ in the milk of dairy cows with a hayconcentrate-feeding type was $0.053 \mathrm{mg} / \mathrm{kg}$ in the first control group, in the second experimental group, where the mineral-vitamin premix "MP-A" was additionally fed to 0.024, and in the third, where Subcutaneous injection of biologically active drug "BP-9" was used up to $0.014 \mathrm{mg} / \mathrm{kg}$; Pb from $1.794 \mathrm{mg} / \mathrm{kg}-\mathrm{to}$ 0.331 and $0.032 \mathrm{mg} / \mathrm{kg}$ respectively; Cu from $2.63 \mathrm{mg} / \mathrm{kg}$ to 0.34 and $0.35 \mathrm{mg} / \mathrm{kg}$ respectively; Zn from $8.74 \mathrm{mg} / \mathrm{kg}$ to 4.97 and $3.87 \mathrm{mg} / \mathrm{kg}$, respectively. Feeding cows to antioxidant premix allows approximately 2-2.5 times to reduce the transition from diet to dairy raw materials that are hazardous to animal health and the quality of milk toxicants for any type of feeding. Future studies are aimed at studying the effects of different types of feeding, taking into account the balancing of diets with a special premix for the production of high-quality, environmentally safe milk.

Key words: diet, premix, bio-preparation, cadmium, lead, copper, zinc, contaminated feed, animal productivity. 


\title{
Вплив типів годівлі корів на вміст важких металів в молоці
}

\author{
О.М. Маменко, С.В. Портянник
}

Харківська державна зооветеринарна академія, м. Харків, Украӥна

Навколо промислових міст склалася складна екологічна ситуачія обумовлена викидами в атмосферу забруднюючих речовин, котрі містять важкі метали, особливо такі небезпечні для довкілля, як кадмій та свинець. Посилення накопиченя даних полютантів у трунтах сільськогосподарських угідь призводить також застосування агрохімікатів - пестицидів і менаральних добрив. В таких екологічних умовах доводиться не лише вирощувати продукцію рослинництва, а й виробляти продукцію тваринництва молоко. Виробництво екологічно безпечного, високоякісного і конкурентоздатного на ринку молока потребує застосування перевірених технологічних прийомів годівлі та утримання тварин. Підбір оптимального типу годівлі корів сприяє зменшенню переходу важких металів в молочну сировину. В експерименті встановлено, щз силосно-коренеплодний тип годівлі мав найменший перехід Cd та Рb з кормів раціону в молочну сировину, коефіцієнт переходу кадмію - 0,24, свинцю - 0,25. Найбільи інтенсивною була міграція Рb з раціону в молоко у корів першої контрольної групи з силосо-сінажно-коцентратним типом годівлі: коефіцієнт переходу становив 0,39, а по Cd-0,34. Аналогічна ситуація була і у корів перших контрольних груп з силосно-сінажним типом годівлі, де коефіцієнт переходу становив 0,36 по Cd та 0,34 по Рb. Загальне надходження важких металів з раціоном за різних типів годівлі практично не відрізнялося. Збалансування раціонів годівлі спеціально розробленим мінерально-вітамінним преміксом “МПA” сприяло зменшенню переходу важких металів $\mathrm{Cd}$, Pb, Cu та $\mathrm{Zn}$ в молоко, при цььому молоко найвищої якості було отримано від корів з силосно-сінажним типом годівлі. В результаті експерименту вдалося досягти позитивного ефекту $і$ знизити вміст важких металів у молочі корів в усіх господарствах з різними типами годівлі тварин за оптимальної якості та безпечності молока, котре відповідало вимогам державного стандарту, в чому переконує коефіиієнт переходу, котрий у корів другої дослідної групи по Сd становив 0,09 у тварин з силосно-коренеплодним типом годівлі; 0,10 - силосно-сінажним; 0,12 - силосно-сінним типом та 0,15 - з силосно-сінажно-концентратним типом відповідно; Pb - 0,01 у корів з силосно-сінажним типом годівлі; 0,07 - силосносінажно-концентратним; 0,08 - силосно-коренеплодним та 0,09 з силосно-сінним типом відповідно; Си - 0,01 у корів з силососінажним та силосно-коренеплодним типом годівлі; 0,02 з силосно-сінажно-концентратним та силосно-сінним типом відповідно; $\mathrm{Zn}$ - 0,05 у тварин з силосно-сінажним типом годівлі; 0,06 - силосно-сінажно-концентратним; 0,08 - силосно-коренеплодним та 0,010 - з силосно-сінним типом відповідно. У третій дослідній групі корів в середньому коефіцієнт переходу важких металів з раціону в молоко щчодо $\mathrm{Cd}, \mathrm{Pb}$, Си та $\mathrm{Zn} \mathrm{становив} \mathrm{0,04.} \mathrm{Застосування} \mathrm{преміксу} \mathrm{та} \mathrm{біопрепарату} \mathrm{знизило} \mathrm{перехід} \mathrm{важких} \mathrm{металів} \mathrm{з}$ раціону в молоко у середньому в 1,5-4,3 разу. Продуктивність тварин становила в середньому у корів другої $і$ третьої дослідних груп 17-22 кг за добу порівняно з контрольною групою - 14 кг. Вміст Cd в молочі дійних корів з силосно-сінажно-кониентратним типом годівлі становив 0,053 мг/кг у першій контрольній групі, у другій дослідній групі, де додатково згодовувався мінеральновітамінний премікс “МП-А”, знизився до 0,024, а у третій, де застосовувалася підшкірна ін'єкція біологічно активного препарату “БП-9” - до 0,014 мг/кг; Рb з 1,794 мг/кг - до 0,331 та 0,032 мг/кг відповідно; Си з 2,63 мг/кг до 0,34 та 0,35 мг/кг відповідно; Zn з 8,74 мг/кг до 4,97 та 3,87 мг/кг відповідно. Згодовування коровам антитоксичного преміксу дозволяє приблизно у 2-2,5 разу знизити перехід з раціону в молочну сировину небезпечних для здоров я тварин і якості молока токсикантів за будь-якого типу годівлі. Майбутні дослідження спрямовані на вивчення впливу різних типів годівлі з урахуванням балансування раціонів спеціальним преміксом для виробництва високоякісного екологічно безпечного молока.

Ключові слова: раціон, премікс, біопрепарат, кадмій, свинець, мідь, ичнк, забруднені корми, продуктивність тварин.

\section{Вступ}

Проведений аналіз вітчизняними та закордонними вченими екологічної ситуації вказує на те, що забруднення довкілля важкими металами за останні десятиліття збільшилося у кілька разів і за прогнозами продовжуватиме зростати (Zasekin, 2000; Bucjak et al., 2005). Негативні еологічні зміни в агроекосистемах посилюються порушеннями норм і правил застосування агрохімікатів: мінеральних добрив та пестицидів. Антропогенний вплив на агроекосистеми навколо промислових міст, в т. ч. через інтенсифікацію ведення традиційного землеробства (надмірне застосування пестицидів, мінеральних добрив), на жаль, посилюється в різних країнах світу (Bigalke et al., 2017). Потрапляння важких металів у грунт може призвести до накопичення небажаних для сільськогосподарських угідь концентрацій, поставити під загрозу родючість, перехід таких полютантів, як $\mathrm{Cd}$ та $\mathrm{Pb}$, 3 грунту в рослини, що йдуть на корм тваринам та можуть входити до раціону будь-якого типу годівлі, здатне ускладнити виробництво високоякісногого молока, а значить i сировини для виробництва харчових продуктів. Підвищена концентрація кадмію і навіть урану у верхньому родючому шарі грунту сільськогосподарських угідь після застосування фосфорних добрив, внесення осаду зі стічних вод, спостерігалася (Bigalke et al., 2017). Вченими досліджено понад 216 сільськогосподарських ділянок грунту в різних регіонах Швейцарії, при цьому мінеральні добрива стають домінуючим джерелом забруднення важкими металами серед усіх інших, враховуючи осідання з атмосферного повітря (Bigalke et al., 2017).

У сільськогосподарських тварин почастішали випадки підвищення рівня важких металів у їхніх органах, тканинах. Інтоксикація $\mathrm{Cd}$ i Pb пов'язана з екологічним ризиком для організму через кумулятивну токсичність та негативний вплив на внутрішні органи й системи (Portjannyk, 2002; Savchenko \& Savchuk, 2013; Canty et al., 2014; Roggeman et al., 2014; Hashemi, 2018). Накопичення важких металів в компонентах біосфери (повітрі, грунті, воді) збільшує небезпеку надходження їх в організм корів і тим самим становить загрозу для здоров’я людини та тварин (Gordijenko et al., 2006; Mamenko et al., 2010; Fischer et al., 2011; Rahimi, 2013; Savchenko \& Savchuk, 2013; Rezza et al., 2018). Навколо промислових міст можуть виникати осередки локального забруднення сільськогосподарських угідь. 
Існує великий обсяг інформації щодо впливу гострої та хронічної форм кадмієвого токсикозу людини й експериментальних тварин (Salvatori et al., 2004; Gutyj et al., 2016). Результати багатьох досліджень вказують на істотні відмінності в ефектах метаболізму одноразових високих доз і тривалого впливу малих доз кадмію. За умов посиленого впливу сполук кадмію виникає анемія, пригнічення функціонального стану імунної системи інші розлади процесів кровотворення, порушення гомеостазу білків тощо (Mamenko \& Portjannyk, 2008; Gutyj et al., 2016; Gutyj et al., 2017; Lavryshyn et al., 2018; Ostapyuk \& Gutyj, 2018; Gutyj et al., 2018).

Сьогодні все більше досліджень вчених пов'язані з вивченням різних ентеросорбентів для посилення виведення важких металів з організму сільськогосподарських тварин. Як джерело мікро- та ультрамікроелементів вивчаються природні кремнеземи, зокрема бентоніти, цеоліти, глауконіти, сапоніти та ін. Ці мінерали мають високі катіонно- i аніонообмінні та сорбційні властивості здатні адсорбувати на своїй поверхні важкі метали з подальшою екскрецією їх 3 організму, навіть того здатні проявляти лікувальний ефект (Kulik et al., 1995; Zasekin, 2000; Bucjak, 2002). Змішанолігандні комплекси $\mathrm{Zn}, \mathrm{Mn}, \mathrm{Co}$, ліквідуючи дефіцит необхідних есенціальних мінеральних елементів в організмі корів, поліпшують мінеральний обмін, тим самим сприяють росту молочної продуктивності (Bomko et al., 2018). Проте екскреція важких металів 3 організму тварин з калом та сечею призводить і до підвищеного їхнього вмісту в органічних добривах (гній і компост), котрі також містять значну кількість важких металів (Gutyj et al., 2016). Внаслідок внесення в грунт таких органічних добрив у ньому зростає концентрація важких металів, таких як кадмій, свинець, мідь, цинк, залізо, марганець тощо.

Враховуючи широкий спектр біологічної і токсичної дії полютантів, зокрема важких металів, що спричиняють зниження продуктивності корів, погіршують якість та екологічну безпеку виробленого молока, стан здоров'я продуктивних тварин, важливе значення має необхідність удосконалення системи ведення тваринництва і годівлі тварин (Portjannyk, 2002; Savchenko \& Savchuk, 2013).

Метою досліджень є оцінка впливу різних типів годівлі дійних корів, які зазнають інтоксикації організму важкими металами $\mathrm{Cd}, \mathrm{Pb}, \mathrm{Cu}, \mathrm{Zn}$ та підбір оптимального типу раціону з одночасним згодовуванням спеціально розробленого мінерально-вітамінного преміксу "МП-А” і підшкірної ін'єкції біопрепарату “БП-9" рослинного походження для виробництва екологічно безпечного молока.

\section{Матеріал і методи досліджень}

В господарствах СТОВ “Удай”, “Світанок”, ССП "Дружба" та СВК "Хорошківський” Лубенського району Полтавської області, розташованих навколо промислового міста, було проведено науковогосподарські досліди на дійних коровах української чорно- та червоно-рябої молочних порід. Для проведення дослідів відібрали 126 голів корів 3 силосно- сінажно-концентратним типом годівлі, 63 - 3 силосносінажним, 36 - силосно-коренеплодним та 195 - 3 силосно-сінним типом годівлі відповідно. Піддослідне поголів'я розподілили на три групи: першу контрольну та другу і третю дослідні групи. Коровам усіх груп згодовували корми з вмістом важких металів $\mathrm{Cd}$, $\mathrm{Pb}, \mathrm{Cu}, \mathrm{Zn}$, вищих за встановлені гранично допустимі концентрації. Тварини другої дослідної групи отримували додатково спеціальний антитоксичний мінерально-вітамінний премікс "МП-А”, а третьої - премікс та підшкірну ін'єкцію біопрепарату “БП-9”, що містить у собі екстракт дев'яти лікарських рослин. Середня жива маса корів - 500-545 кг, середньодобовий надій - 14,0-14,8 кг, що за лактацію складає в середньому 4270-4514 кг молока. Тривалість порівняльного періоду становила 42 дні. Корови були підібрані методом аналогів за живою масою, продуктивністю і перебували в однакових умовах годівлі та утримання. Дослідний період тривав 120 днів.

Мінерально-вітамінний премікс та біологічно активний препарат “БП-9” розроблено за методикою (Portjannyk, 2002). Біопрепарат “БП-9” - екстракт з 9 лікарських рослин. В 100 мл препарату міститься: лимонника китайського (англ. Schisandra chinensis) 15 мл, ромашки лікарської (аптечна, обідрана) (англ. Chamomile ) - 3 мл, елеутерокока колючого (англ. Eleutherococcus senticosus) - 15 мл, шавлії лікарської (аптечної) (англ. Salvia officinalis) - 17 мл, барбарису звичайного (англ. Berberis) - 12 мл, люцерни посівної (англ. Alfalfa) - 5 мл, ниркового чаю (англ. Orthosiphon stamineus) - 15 мл, обліпихи крушиновидної (англ. Hippophae rhamnoides) - 15 мл, вербени лікарської (англ. Verbena officinalis) - 3 мл. Застосовано підшкірну ін'єкцію. Доза введення препарату “БП-9” - 20 мл/добу з поділом цієї норми на дві по 10 мл кожна вранці і через інтервал 12 годин ввечері. Кратність введення препарату - 5 разів на місяць, 3 інтервалом введення - один раз на 6 днів. Використано препарату для ін'єкції 42 голів корів третьої дослідної групи з силосно-сінажно-концентратним типом годівлі 16.8 л (20 мл $\times 20$ (5 разів на місяць $\times$ на 4 місяці досліду) $=400$ мл); силосно-сінажним -21 голови - 8,4 л; силосно-коренеплодним - 12 голів 4,8 л; силосно-сінним - 65 голів - 26 літрів відповідно. Форма випуску - склянні флакони об'ємом 250 мл. Біопрепарат виготовлено в стерильних умовах виробничої лабораторії за методикою (Hmel'nic'kij et al., 1994; Sokolov et al., 2002). В других і третіх дослідних групах розроблені нами раціони годівлі дійних корів були додатково збалансовані адаптованим до фактичного добового раціону годівлі спеціальним антитоксичним мінерально-вітамінним преміксом "МП-А". Премікси розроблено з урахуванням синергічної, антагоністичної дії макро-, мікроелементів щодо кадмію, свинцю, міді та цинку, з урахуванням їх концентрації на 1 кг сухої речовини, що дало можливість розробити нам методичний підхід до нормування вмісту в раціоні важких металів і відповідної кількості (співвідношення) ессенціальних макро-, мікроелементів, частковий дефіцит котрих спостерігався в раціонах корів контрольних груп. До складу мінерально-вітамінного преміксу "МП-А” входили такі мі- 
неральні елементи: P, Ca, Mg, S, Fe, Mn, Co, J, Se i iн.; вітаміни: A, D, E, B2, B3 (ніацин, РP), B4, B6, C, Н (Biotin) та одна із сірковмісних амінокислот. Згодовування преміксу з розрахунку введення до складу раціону 1\% (Podobed et al., 1996) становило: для корів 3 силосно-коренеплодним та силосно-сінним типом годівлі 250 г на голову за добу, силосно-сінажноконцентратним - 290 г, силосно-сінажним - 255 г відповідно. Згодовано преміксу "МП-А" для 24 голів дійних корів другої і третьої дослідних груп з силосно-коренеплодним типом годівлі 720 кг (250 г на голову за добу $\times 24$ голови $\times 120$ днів досліду); силосносінним - 130 голів - 3900 кг; силосно-сінажним - 42 голови - 1285.2 кг; силосно-сінажно-концентратним 84 голови - 2923,2 кг відповідно. На ринку працює велика кількість регіональних фірм, котрі на замовлення за відповідним раціоном та рецептом можуть виготовити i реалізувати агропідприємству такий премікс, а це робить його достатньо зручним у використанні, що враховано нами при проведенні дослідів. В межах господарських договорів усі піддослідні господарства співпрацювали 3 такою фірмою, тож виробництво та постачання преміксу разом 3 іншою продукцією - звичайна господарська діяльність.

Рецепт (формула) преміксу “МП-А”, препарату “БП-9”, методика розробки адаптованого до фактичних добових раціонів годівлі мінерально-вітамінного преміксу "МП-А” належить авторам даної публікації Маменку О.М. та Портяннику С.В. (Україна).

Біохімічний аналіз зразків рослинного і тваринного походження: кормів, крові, внутрішніх органів i тканин, сечі та молока на вміст макро-, мікроелементів в т. ч. важких металів і ін. проведено методом атомно-абсорбційної спектрофотометрії (спектрофотометр AAS-30) (Praice, 1972). Котроль якості та екологічної безпеки молока здійснювався за ДСТУ $3662-$ 97 (Mamenko et al., 1997), а також з урахуванням вимог міжнародних стандартів якості (Регламент (СС) №853/2004 та №1881/2006).

Коефіцієнт переходу (КП) важких металів в ланцюгу "раціон $\rightarrow$ продукція (молоко)" визначали за формулою: КП = Ввмп / Ввмр $\times 100$, де КП - коефіцієнт переходу; Ввмп - вміст важких металів в продукції (молоці) тварин, мг/кг; Ввмр - вміст важких металів в раціоні, мг. Даний коефіцієнт є відносним інтегрованим показником, котрий у \% відображає міграцію важких металів з раціону в молоко, що дозволяє провести порівняльну оцінку переходу полютантів за різних типів годівлі корів та одночасного застосування антидот них речовин - преміксу і біопрепарату.

Усі маніпуляції з тваринами проводили відповідно до Свропейської конвенції про захист хребетних тварин, яких використовують 3 експериментальною та науковою метою (Страсбург, 1986 рік).
Аналіз даних проводився з урахуванням особливостей отриманих у дослідженні результатів: розміру вибірки та типу розподілу даних, характеру дисперсій. Для кожної вибірки розраховано середнє значення ознаки у виборці (M) та стандартне відхилення (SD), оцінка наводиться у вигляді $\mathrm{M} \pm \mathrm{SD}$. Розбіжності між середніми значеннями вважали статистично вірогідними за $\mathrm{P}<0,05$. Розрахунок проводився в пакеті програм STATISTICA версії 10.0 для операційної системи Windows 7.

\section{Результати}

Внаслідок забруднення навколишнього середовища навколо промислового міста утворилися осередки локального підвищеного вмісту важких металів у компонентах біосфери, зокрема у грунті. Посилення негативного антропогенного впливу на довкілля здійснювали також газоконденсатна станція та інтенсивне застосування агрохімікатів - мінеральних добрив, пестицидів, котрі спричинили посилення міграції важких металів, особливо таких, як $\mathrm{Cd}$ i Pb, з грунту в рослини - відповідно в корми раціону годівлі корів. Концентрація кадмію в раціоні корів 3 силоснокоренеплодним типом годівлі перевищувала встановлені норми у середньому в 2,1-3,2 разу, $\mathrm{Pb}-2,4-5,7$ разу, $\mathrm{Cu}-1,4-2,3$ і Zn - 1,2-2,4 разу відповідно. Найбільше перевищення гранично допустимої концентрації (ГДК) по $\mathrm{Cd}$ і $\mathrm{Pb}$ було в сіні злаково-бобовому (3,2 і 5,7 разу), $\mathrm{Cu}$ - в дерті кукурудзяній (2,3 разу), $\mathrm{Zn}$ - у соломі пшеничній (2,4 разу). Вміст важких металів в кормах раціону корів з іншими типами годівлі був різним, адже суттєвий вплив на міграцію елементів з грунту в рослини обумовлює наявність рухомих форм, а також віддаленість сільськогосподарських угідь від джерела забруднення. В кормах корів 3 силосно-сінним типом годівлі найбільший вміст кадмію, свинцю, міді, цинку виявлено в кормових буряках відповідно в 2,5; 3,4; 3,8; та 4,1 разу. Рослини переважно акумулюють важкі метали в кореневій системі, у вегетативну частину їх потрапляє дещо менше, тому зі всіх кормів кормові буряки мали найбільший рівень забруднення за всіма досліджуваними елементами порівняно 3 іншими кормами. В рослинах, вирощених на сільськогосподарських угіддях, де коровам згодовувався раціон силосно-сінажного типу, окрім надлишку вмісту $\mathrm{Cd}, \mathrm{Pb}, \mathrm{Cu}, \mathrm{Zn}$, порівняно 3 іншими дослідами, зафіксовано високу концентрацію цинку в зерні вівса та гороху, що в середньому перевищувало ГДК в 6,3-6,8 разу. Найбільший вміст $\mathrm{Cd}$ i $\mathrm{Pb}$ серед решти кормів мала дерть горохова, а міді сіно злаково-бобове (3,9 разу).

На рисунку 1 розміщено типи годівлі дійних корів залежно від рівня забруднення кормів раціону $\mathrm{Cd}, \mathrm{Pb}$, $\mathrm{Cu}, \mathrm{Zn}$. 


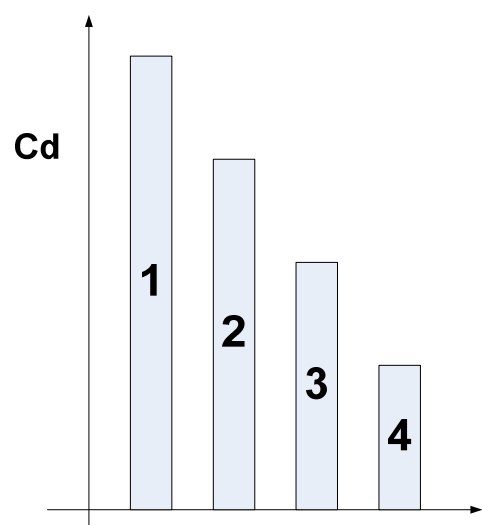

Тип годівлі

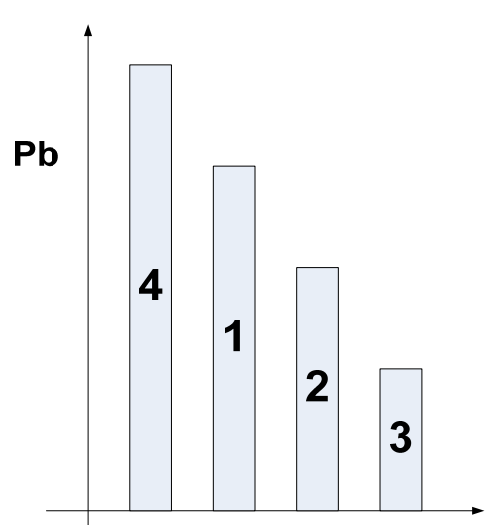

Тип годівлі

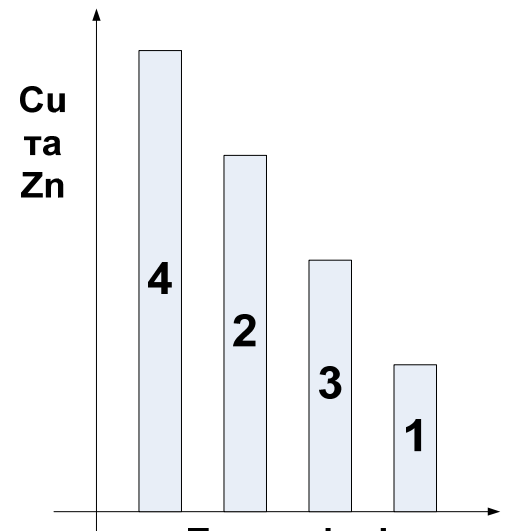

Тип годівлі

Рис. 1. Розташування типів годівлі дійних корів за рівнем забруднення кормів раціону важкими металами 1 - силосно-коренеплодний; 2 - силосно-сінажний; 3 - силосно-сінний; 4 - силосно-сінажно-концентратний

У таблиці 1 наведено загальну концентрацію важких металів в добовому раціоні дійних корів, котра обумовлена кормами відповідної якості та екологічної безпеки в чотирьох різних господарствах розташованих навколо промислового міста, де утримувалися тварини з різними типами годівлі. Додатково всі раці- они були збалансовані спеціально розробленим антитоксичним мінерально-вітамінним преміксом “МПA". Також в таблиці 1 вказано вміст важких металів в молоці корів піддослідних груп в кінці досліду та коефіцієнт переходу мінеральних елементів з раціону в готову продукцію - молочну сировину.

\section{Таблиця 1}

Вміст мінеральних елементів та важких металів у раціоні та молоці корів і коефіцієнт переходу їх 3 раціону в молоко $(\mathrm{M} \pm \mathrm{SD})$

\begin{tabular}{|c|c|c|c|c|c|c|c|c|}
\hline \multirow{3}{*}{$\begin{array}{c}\text { Тип годівлі } \\
\text { тварин }\end{array}$} & \multirow{3}{*}{ Метал } & \multicolumn{7}{|c|}{ Фактична концентрація } \\
\hline & & \multirow{2}{*}{$\begin{array}{c}\text { Раціон, мг/гол } \\
1 \text { кон. та } \\
2 \text { i } 3 \text { дослідна }\end{array}$} & \multicolumn{3}{|c|}{ Молоко, мг/кг } & \multicolumn{3}{|c|}{ КП } \\
\hline & & & 1 кон. & 2 дос. & 3 дос. & 1 кон. & 2 дос. & 3 дос. \\
\hline \multirow{4}{*}{$\begin{array}{c}\text { Силосно- } \\
\text { коренеплодний }\end{array}$} & $\mathrm{Cd}$ & 35,85 & $0,087 \pm 0,008$ & $0,031 \pm 0,005$ & $0,018 \pm 0,002$ & 0,24 & 0,09 & 0,05 \\
\hline & $\mathrm{Pb}$ & 738,74 & $1,835 \pm 0,093$ & $0,614 \pm 0,085$ & $0,014 \pm 0,003$ & 0,25 & 0,08 & 0,01 \\
\hline & $\mathrm{Cu}$ & 2542,56 & $2,47 \pm 0,38$ & $0,31 \pm 0,14$ & $0,29 \pm 0,09$ & 0,10 & 0,01 & 0,01 \\
\hline & $\mathrm{Zn}$ & 7895,19 & $7,06 \pm 0,32$ & $6,01 \pm 0,27$ & $4,32 \pm 0,84$ & 0,09 & 0,08 & 0,06 \\
\hline \multirow{4}{*}{$\begin{array}{c}\text { Силосно- } \\
\text { сінний }\end{array}$} & $\mathrm{Cd}$ & 26,64 & $0,09 \pm 0,085$ & $0,031 \pm 0,008$ & $0,011 \pm 0,003$ & 0,34 & 0,12 & 0,04 \\
\hline & $\mathrm{Pb}$ & 606,65 & $1,641 \pm 0,253$ & $0,515 \pm 0,064$ & $0,027 \pm 0,012$ & 0,27 & 0,09 & 0,01 \\
\hline & $\mathrm{Cu}$ & 3728,43 & $2,54 \pm 0,42$ & $0,57 \pm 0,26$ & $0,32 \pm 0,06$ & 0,07 & 0,02 & 0,01 \\
\hline & $\mathrm{Zn}$ & 6306,15 & $9,93 \pm 0,72$ & $6,14 \pm 0,56$ & $4,17 \pm 0,62$ & 0,16 & 0,10 & 0,07 \\
\hline \multirow{4}{*}{$\begin{array}{l}\text { Силосно- } \\
\text { сінажний }\end{array}$} & $\mathrm{Cd}$ & 18,95 & $0,068 \pm 0,017$ & $0,017 \pm 0,004$ & $0,012 \pm 0,002$ & 0,36 & 0,10 & 0,06 \\
\hline & $\mathrm{Pb}$ & 517,97 & $1,734 \pm 0,148$ & $0,016 \pm 0,004$ & $0,014 \pm 0,004$ & 0,34 & 0,01 & 0,01 \\
\hline & $\mathrm{Cu}$ & 2128,34 & $2,36 \pm 0,39$ & $0,28 \pm 0,09$ & $0,27 \pm 0,15$ & 0,11 & 0,01 & 0,01 \\
\hline & $\mathrm{Zn}$ & 7565,6 & $7,93 \pm 0,23$ & $4,02 \pm 0,16$ & $3,51 \pm 0,39$ & 0,11 & 0,05 & 0,05 \\
\hline \multirow{4}{*}{$\begin{array}{c}\text { Силосно- } \\
\text { сінажно- } \\
\text { концентратний }\end{array}$} & $\mathrm{Cd}$ & 15,77 & $0,053 \pm 0,019$ & $0,024 \pm 0,009$ & $0,014 \pm 0,004$ & 0,34 & 0,15 & 0,09 \\
\hline & $\mathrm{Pb}$ & 455,64 & $1,794 \pm 0,165$ & $0,331 \pm 0,064$ & $0,032 \pm 0,008$ & 0,39 & 0,07 & 0,01 \\
\hline & $\mathrm{Cu}$ & 1798,64 & $2,63 \pm 0,42$ & $0,34 \pm 0,12$ & $0,35 \pm 0,17$ & 0,15 & 0,02 & 0,02 \\
\hline & $\mathrm{Zn}$ & 8619,5 & $8,74 \pm 0,40$ & $4,97 \pm 0,30$ & $3,87 \pm 0,20$ & 0,10 & 0,06 & 0,05 \\
\hline
\end{tabular}

Примітка: ступінь вірогідності порівняно з даними контрольної групи $\mathrm{P}<0,01 ; \mathrm{n}=5$

Для встановлення відповідності отриманих даних закону “нормального" розподілу (Гауссова) нами застосовано тест Шапіро-Уілка (Shapiro-Wilk's W test), що вважається найпотужнішим, особливо за невеликих вибірок $(\mathrm{n}<50)$ незалежних груп. Вміст $\mathrm{Cd}, \mathrm{Pb}, \mathrm{Cu}$ й $\mathrm{Zn}$, в молоці корів 3 силосокоренеплодним типом годівлі не підпорядковується закону нормального розподілу (рис. 2-3).

Так само не підпорядковуються закону нормального розподілу показники в інших піддослідних групах 3 силосо-сінажним, силосно-сінним та силосносінажно-концентратним типами годівлі.
Тест Шапіро-Уілка дозволив визначити відповідний метод подальшого аналізу порівняння вибірок. Враховуючи те, що об'єм вибірок незначний, найбільш ефективним $є$ спосіб застосування непараметричного дисперсійного аналізу Крускала-Уолліса (або Н-тест) (Kruskal-Wallis ANOVA) (рис. 4). 
a

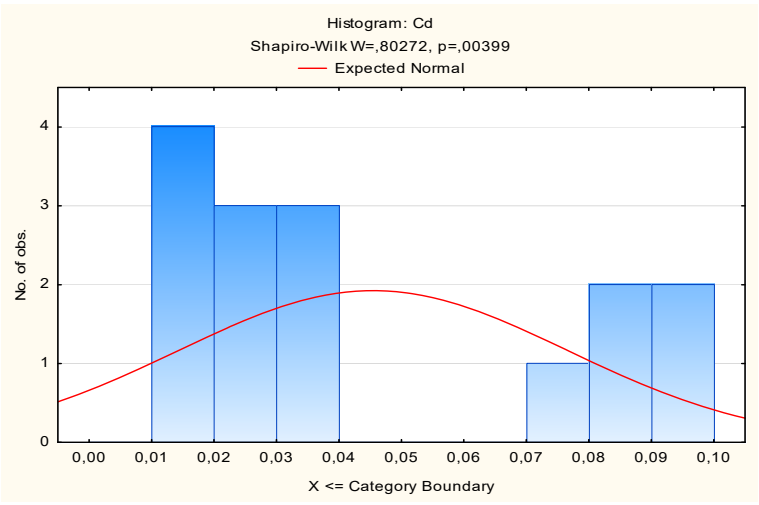

6

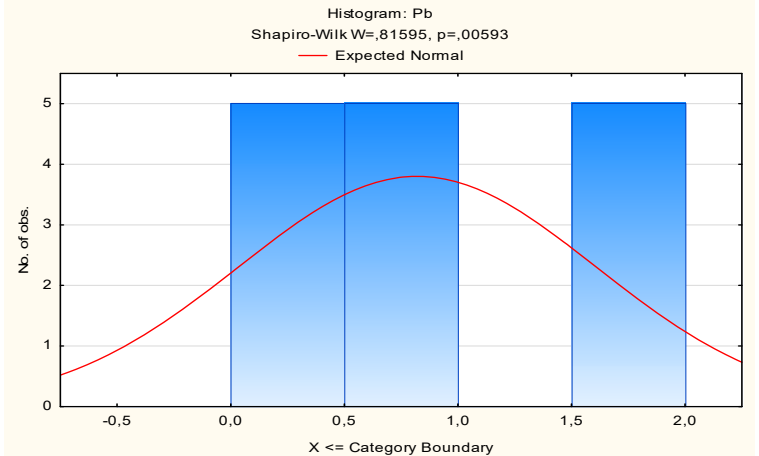

Рис. 2. Результат аналізу розподілу досліджуваних показників (вміст $\mathrm{Cd}(\mathrm{a}), \mathrm{Pb}(б)$ в молоці (мг/кг) корів за тестом Шапіро-Уілка

a

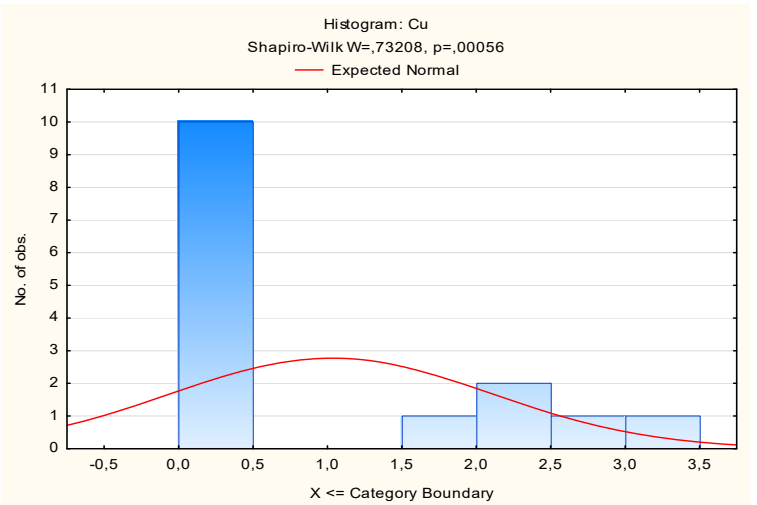

6

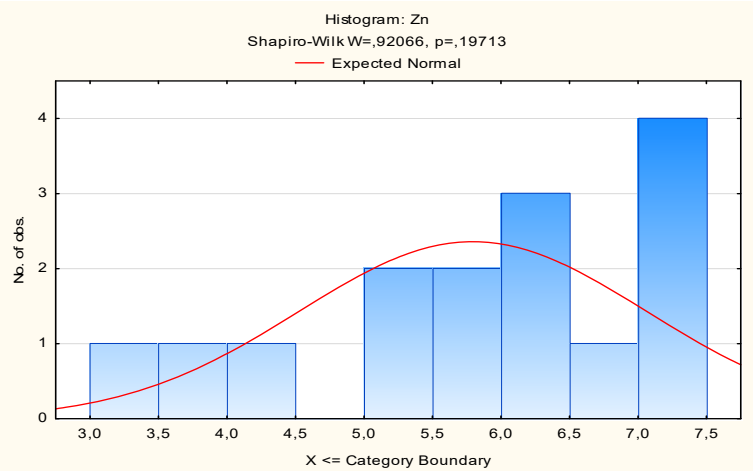

Рис. 3. Результат аналізу розподілу досліджуваних показників (вміст $\mathrm{Cu}(\mathrm{a}), \mathrm{Zn}$ (б) в молоці (мг/кг) корів за тестом Шапіро-Уілка a

\begin{tabular}{|c|c|c|c|c|c|}
\hline \multirow[b]{2}{*}{$\begin{array}{l}\text { Depend: } \\
\text { Cd }\end{array}$} & \multicolumn{5}{|c|}{$\begin{array}{l}\text { Kruskal-Wallis ANOVA by Ranks; Cd (Spreadsheet } 1 \text { ) } \\
\text { Independent (grouping) variable: Group } \\
\text { Kruskal-Wallis test: } \mathrm{H}(2, \mathrm{~N}=15)=12,50000 \mathrm{p}=, 0019\end{array}$} \\
\hline & Code & \begin{tabular}{|c|} 
Valid \\
$\mathrm{N}$
\end{tabular} & $\begin{array}{l}\text { Sum of } \\
\text { Ranks }\end{array}$ & $\begin{array}{l}\text { Mean } \\
\text { Rank }\end{array}$ & \\
\hline 1 & 1 & 5 & 65,00000 & 13,00000 & \\
\hline 2 & 2 & 5 & 40,00000 & 8,00000 & \\
\hline 3 & 3 & 5 & 15,00000 & 3,00000 & \\
\hline
\end{tabular}

\begin{tabular}{|l|r|r|r|r|}
\hline \hline & \multicolumn{4}{|l|}{$\begin{array}{l}\text { Kruskal-Wallis ANOVA by Ranks; Pb (Spreadsheet1) } \\
\text { Independent (grouping) variable: Group } \\
\text { Kruskal-Wallis test: } \mathrm{H}(2, \mathrm{~N}=15)=12,50000 \mathrm{p}=, 0019\end{array}$} \\
\cline { 2 - 5 } $\begin{array}{l}\text { Kepend.: } \\
\mathrm{Pb}\end{array}$ & Code & $\begin{array}{c}\text { Valid } \\
\mathrm{N}\end{array}$ & $\begin{array}{c}\text { Sum of } \\
\text { Ranks }\end{array}$ & $\begin{array}{c}\text { Mean } \\
\text { Rank }\end{array}$ \\
\hline $\mathbf{1}$ & 1 & 5 & 65,00000 & 13,00000 \\
\hline 2 & 2 & 5 & 40,00000 & 8,00000 \\
\hline 3 & 3 & 5 & 15,00000 & 3,00000 \\
\hline
\end{tabular}

B

\begin{tabular}{|c|c|c|c|c|c|}
\hline \multirow[b]{2}{*}{$\begin{array}{l}\text { Depend: } \\
\mathrm{Cu}\end{array}$} & \multicolumn{5}{|c|}{$\begin{array}{l}\text { Kruskal-Wallis ANOVA by Ranks; Cu (Spreadsheet1) } \\
\text { Independent (grouping) variable: Group } \\
\text { Kruskal-Wallis test: } \mathrm{H}(2, \mathrm{~N}=15)=9,420000 \mathrm{p}=, 0090\end{array}$} \\
\hline & Code & $\begin{array}{c}\text { Valid } \\
\mathrm{N}\end{array}$ & $\begin{array}{l}\text { Sum of } \\
\text { Ranks } \\
\end{array}$ & $\begin{array}{l}\text { Mean } \\
\text { Rank } \\
\end{array}$ & \\
\hline 1 & 1 & 5 & 65,00000 & 13,00000 & \\
\hline 2 & 2 & 5 & 29,00000 & 5,80000 & \\
\hline 3 & 3 & 5 & 26,00000 & 5,20000 & \\
\hline \multicolumn{6}{|l|}{$\Gamma$} \\
\hline & \multicolumn{5}{|c|}{$\begin{array}{l}\text { Kruskal-Wallis ANOVA by Ranks; } \mathrm{Zn} \text { (Spreadsheet1) } \\
\text { Independent (grouping) variable: Group } \\
\text { Kruskal-Wallis test: } \mathrm{H}(2, \mathrm{~N}=15)=12,50000 \mathrm{p}=, 0019\end{array}$} \\
\hline $\begin{array}{l}\text { Depend.: } \\
\text { Zn }\end{array}$ & \begin{tabular}{|l|} 
Code \\
\end{tabular} & $\begin{array}{c}\text { Valid } \\
\mathrm{N}\end{array}$ & $\begin{array}{l}\text { Sum of } \\
\text { Ranks }\end{array}$ & $\begin{array}{l}\text { Mean } \\
\text { Rank }\end{array}$ & \\
\hline 1 & 1 & 5 & 65,00000 & 13,00000 & \\
\hline 2 & 2 & 5 & 40,00000 & 8,00000 & \\
\hline 3 & 3 & 5 & 15,00000 & 3,00000 & \\
\hline
\end{tabular}

Рис. 4. Наведено величину похибки Р для нульової гіпотези про те, що вміст $\mathrm{Cd}(\mathrm{a}), \mathrm{Pb}($ б), $\mathrm{Cu}$ (в) й $\mathrm{Zn}$ (г) в молоці корів 3 силосо-коренеплодним типом годівлі

у різних піддослідних групах не відрізняється,

в нашому випадку $\mathrm{P}<0,05$ - досліджувані групи статистично вірогідно відрізняються одна від одної

На рисунку 5 наведено показники описувальної статистики.

Оскільки отримані нами експериментальні дані не підпорядковуються закону нормального розподілу, ми вважаємо необхідним навести як середньо арифметичні значення досліджуваних показників у групах, так і медіану 3 нижньою та верхньою квартілями (рис. 69). Відмінність між середніми значеннями показників та їх медіаною незначна і не має в даному експерименті суттєвого впливу на результати досліджень.

Для зменшення токсичної дії важких металів, зокрема кадмію та свинцю, і їх переходу в молоко, усі раціони, незалежно від типу годівлі, були додатково збалансовані спеціальним мінерально-вітамінним преміксом “МП-А”. Крім того, для посилення протекторної дії преміксу застосовувался підшкірна ін'єкція біологічно-активного препарату “БП-9”. Розроблені нами премікси адаптовані до фактичних раціонів годівлі корів. Під час балансування раціонів спостерігався дефіцит ессенціальних макро-, мікроелементів в кормах основного раціону корів у всіх чотирьох дослідах на фоні підвищеного рівня важких металів $\mathrm{Cd}$, $\mathrm{Pb}, \mathrm{Cu}, \mathrm{Zn}$. 
Науковий вісник ЛНУВМБ імені С.3. Гжицького. Серія: Сільськогосподарські науки, 2019, т 21, № 90

\begin{tabular}{|c|c|c|c|c|c|c|c|c|c|}
\hline \multirow[b]{2}{*}{ Variable } & \multicolumn{9}{|c|}{ Descriptive Statistics (Spreadsheet1) } \\
\hline & Valid N & $\%$ Valid obs. & Mean & Median & Sum & Minimum & Maximum & Std.Dev. & $\begin{array}{l}\text { Standard } \\
\text { Error }\end{array}$ \\
\hline Group 1 & 5 & 33,33333 & 0,086600 & 0,087000 & 0,433000 & 0,076000 & 0,096000 & 0,008264 & 0,003696 \\
\hline \multirow{3}{*}{$\begin{array}{l}\text { Variable } \\
\text { Group 2 }\end{array}$} & \multicolumn{9}{|c|}{ Descriptive Statistics (Spreadsheet1) } \\
\hline & Valid $N$ & $\%$ Valid obs. & Mean & Median & Sum & Minimum & Maximum & Std.Dev. & $\begin{array}{c}\text { Standard } \\
\text { Error }\end{array}$ \\
\hline & 5 & 33,33333 & 0,031400 & 0,031000 & 0,157000 & 0,025000 & 0,040000 & 0,005683 & 0,002542 \\
\hline & \multicolumn{9}{|c|}{ Descriptive Statistics (Spreadsheet1) } \\
\hline Variable & Valid $N$ & $\%$ Valid obs. & Mean & Median & Sum & Minimum & Maximum & Std.Dev. & $\begin{array}{c}\text { Standard } \\
\text { Error }\end{array}$ \\
\hline Group 3 & 5 & 33,33333 & 0,018400 & 0,019000 & 0,092000 & 0,015000 & 0,021000 & 0,002408 & 0,001077 \\
\hline
\end{tabular}

\begin{tabular}{|l|r|r|c|c|c|c|c|c|c|}
\hline & \multicolumn{2}{|l|}{ Descriptive Statistics (Spreadsheet1) } \\
\cline { 2 - 10 } & Valid N & \% Valid obs. & Mean & Median & Sum & Minimum & Maximum & Std.Dev. & $\begin{array}{c}\text { Standard } \\
\text { Error }\end{array}$ \\
\hline Gariable & & & & & & & & & \\
\hline
\end{tabular}

\begin{tabular}{|c|c|c|c|c|c|c|c|c|c|}
\hline \multirow[b]{2}{*}{ Variable } & \multicolumn{9}{|c|}{ Descriptive Statistics (Spreadsheet1) } \\
\hline & Valid N & $\%$ Valid obs. & Mean & Median & Sum & Minimum & Maximum & Std.Dev. & $\begin{array}{c}\text { Standard } \\
\text { Error }\end{array}$ \\
\hline Group 2 & 5 & 33,33333 & 0,614200 & 0,598000 & 3,071000 & 0,538000 & 0,757000 & 0,085268 & 0,038133 \\
\hline
\end{tabular}

\begin{tabular}{|l|l|l|l|l|l|l|l|l|l|}
\hline \multirow{3}{*}{\begin{tabular}{l} 
Variable \\
\cline { 2 - 9 }
\end{tabular}} & \multicolumn{2}{|l|}{ Descriptive Statistics (Spreadsheet1) } \\
\hline Valid N & \% Valid obs. & Mean & Median & Sum & Minimum & Maximum & Std.Dev. & $\begin{array}{c}\text { Standard } \\
\text { Error }\end{array}$ \\
\hline Group 3 & 5 & 33,33333 & 0,014400 & 0,014000 & 0,072000 & 0,011000 & 0,019000 & 0,003209 & 0,001435 \\
\hline
\end{tabular}

\begin{tabular}{|c|c|c|c|c|c|c|c|c|c|c|c|}
\hline \multirow[b]{2}{*}{ Variable } & \multicolumn{11}{|c|}{ Descriptive Statistics (Spreadsheet1) } \\
\hline & Valid N & $\%$ Valid obs. & Mean & Median & Sum & Minimum & Maximum & $\begin{array}{c}\text { Lower } \\
\text { Quartile }\end{array}$ & $\begin{array}{c}\text { Upper } \\
\text { Quartile }\end{array}$ & Std.Dev. & $\begin{array}{c}\text { Standard } \\
\text { Error }\end{array}$ \\
\hline Group 1 & 5 & 33,33333 & 2,470000 & 2,470000 & 12,35000 & 1,940000 & 3,010000 & 2,410000 & 2,520000 & 0,380329 & 0,170088 \\
\hline
\end{tabular}

\begin{tabular}{|c|c|c|c|c|c|c|c|c|c|c|c|c|c|c|}
\hline Group 1 & 5 & & 33,33333 & \multicolumn{2}{|c|}{2,470000} & 2,47000 & \begin{tabular}{l|l}
00 & 12,35000
\end{tabular} & 1,940000 & 3,0100002 & 2,410000 & \multicolumn{2}{|c|}{2,520000} & 0,380329 & 0,170088 \\
\hline & \multicolumn{14}{|c|}{ Descriptive Statistics (Spreadsheet1) } \\
\hline Variable & Valid $\mathrm{N}$ & $\%$ & Valid obs. & $\mathrm{Me}$ & & Median & Sum & Minimum & Maximum & $\begin{array}{c}\text { Lower } \\
\text { Quartile }\end{array}$ & \multicolumn{2}{|c|}{$\begin{array}{c}\text { Upper } \\
\text { Quartile }\end{array}$} & Std.Dev. & $\begin{array}{c}\text { Standard } \\
\text { Error }\end{array}$ \\
\hline Group 2 & 5 & & 33,33333 & 0,314 & 4000 & 0,31000 & $00 \quad 1,570000$ & 0,140000 & 0,480000 & 0,230000 & \multicolumn{2}{|c|}{0,410000} & 0,136125 & \begin{tabular}{l|l|}
5 & 0,060877 \\
\end{tabular} \\
\hline & \multicolumn{14}{|c|}{ Descriptive Statistics (Spreadsheet1) } \\
\hline Variable & Valid N & $\%$ & Valid obs. & $\mathrm{Me}$ & & Median & Sum & Minimum & Maximum & $\begin{array}{c}\text { Lower } \\
\text { Quartile }\end{array}$ & \multicolumn{2}{|c|}{\begin{tabular}{|c|} 
Upper \\
Quartile \\
\end{tabular}} & Std.Dev. & $\begin{array}{l}\text { Standard } \\
\text { Error }\end{array}$ \\
\hline Group 3 & 5 & & 33,33333 & 0,294 & 4000 & 0,28000 & \begin{tabular}{l|l}
00 & 1,470000 \\
\end{tabular} & 0,210000 & 0,4400000 & 0,220000 & \multicolumn{2}{|c|}{0,320000} & 0,093167 & 0,041665 \\
\hline & \multicolumn{14}{|c|}{ Descriptive Statistics (Spreadsheet1) } \\
\hline Variable & \multicolumn{2}{|c|}{ Valid N } & \multicolumn{2}{|c|}{$\%$ Valid obs. } & \multicolumn{2}{|c|}{ Mean } & Median & Sum & Minimum & \multicolumn{2}{|c|}{ Maximum } & \multicolumn{2}{|c|}{ Std.Dev. } & $\begin{array}{c}\text { Standard } \\
\text { Error }\end{array}$ \\
\hline Group 1 & & 5 & \multicolumn{2}{|c|}{33,33333} & \multicolumn{2}{|c|}{7,056000} & 7,180000 & 35,28000 & 6,530000 & \multicolumn{2}{|c|}{7,340000} & \multicolumn{2}{|c|}{0,316907} & 0,141725 \\
\hline
\end{tabular}

\begin{tabular}{|c|c|c|c|c|c|c|c|c|c|}
\hline Variable & \multicolumn{9}{|c|}{ Descriptive Statistics (Spreadsheet1) } \\
\hline & \multicolumn{9}{|c|}{ Descriptive Statistics (Spreadsheet1) } \\
\hline Variable & Valid N & $\%$ Valid obs. & Mean & Median & Sum & Minimum & Maximum & Std.Dev. & $\begin{array}{c}\text { Standard } \\
\text { Error }\end{array}$ \\
\hline Group 3 & 5 & 33,33333 & 4,322000 & 4,210000 & 21,61000 & 3,430000 & 5,330000 & 0,837299 & 0,374452 \\
\hline
\end{tabular}

Рис. 5. Описувальна статистика досліджуваних показників: середнього арифметичного М (Mean), стандартного відхилення SD (Std. Dev.), медіани (Median), нижньої і верхньої квартілі (Lower Quartile; Upper Quartile) та ін. вмісту $\mathrm{Cd}(\mathrm{a}), \mathrm{Pb}($ б), $\mathrm{Cu}$ (в) й $\mathrm{Zn}$ (г) в молоці корів трьох піддослідних груп з силосно-коренеплодним типом годівлі 
a

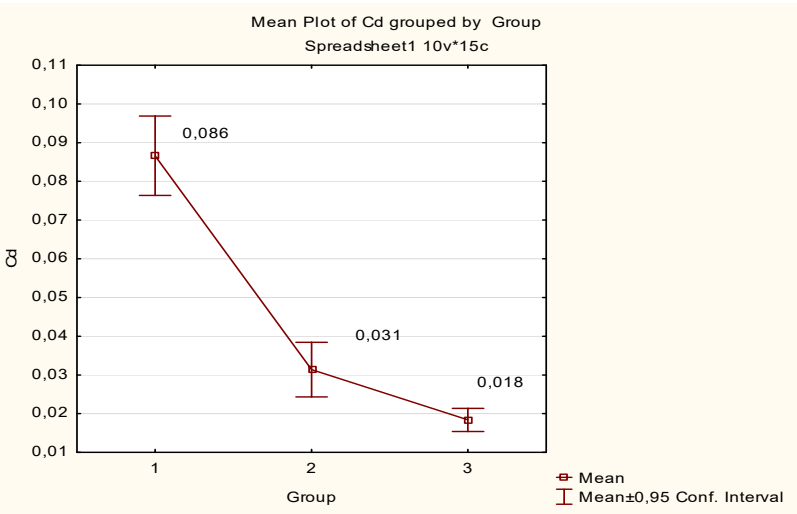

б

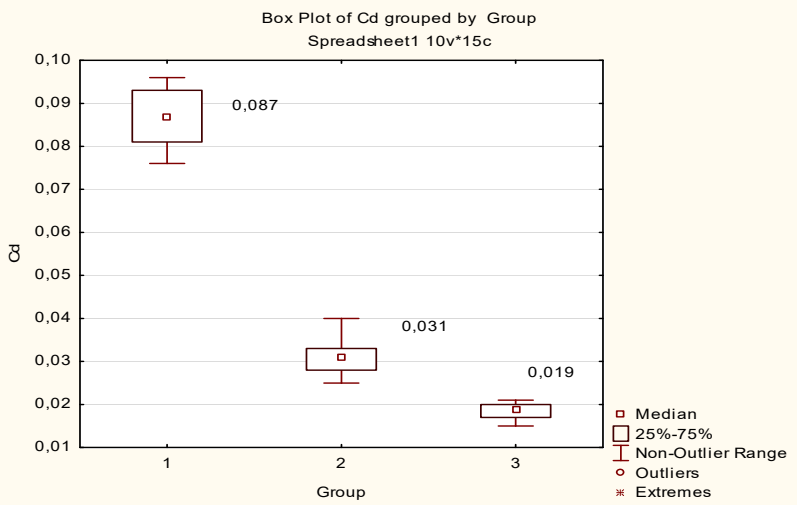

Рис. 6. Діаграма середніх значень (а) та квартільна діаграма (б) вмісту Сd в молоці (мг/кг) корів трьох піддослідних груп з силосно-коренеплодним типом годівлі

$\mathrm{a}$

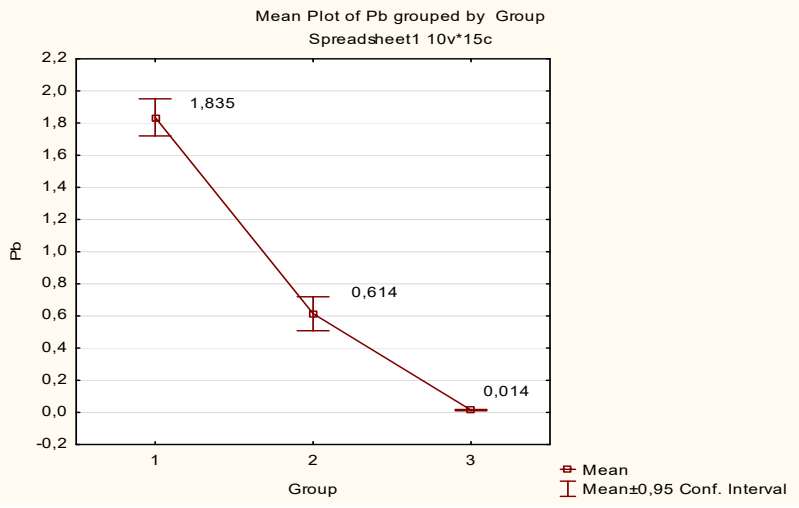

6

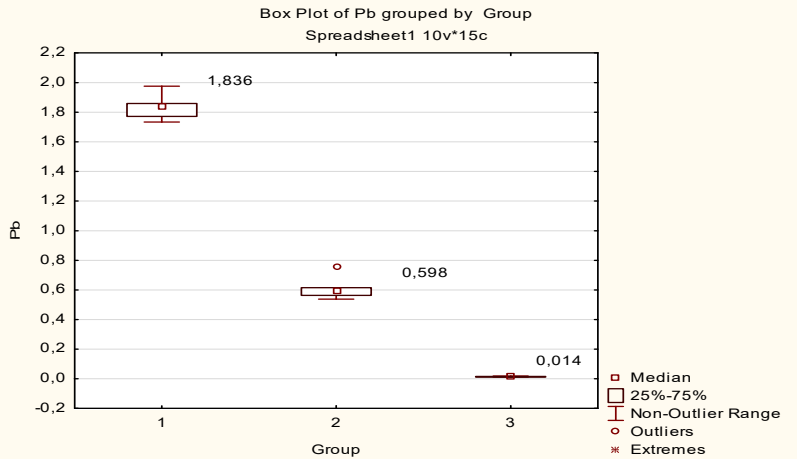

Рис. 7. Діаграма середніх значень (а) та квартільна діаграма (б) вмісту $\mathrm{Pb}$ в молоці (мг/кг) корів трьох піддослідних груп з силосно-коренеплодним типом годівлі a

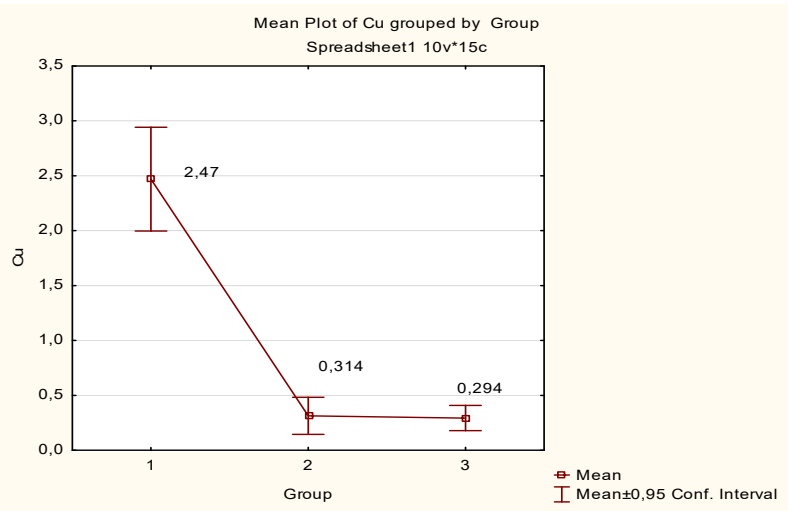

6

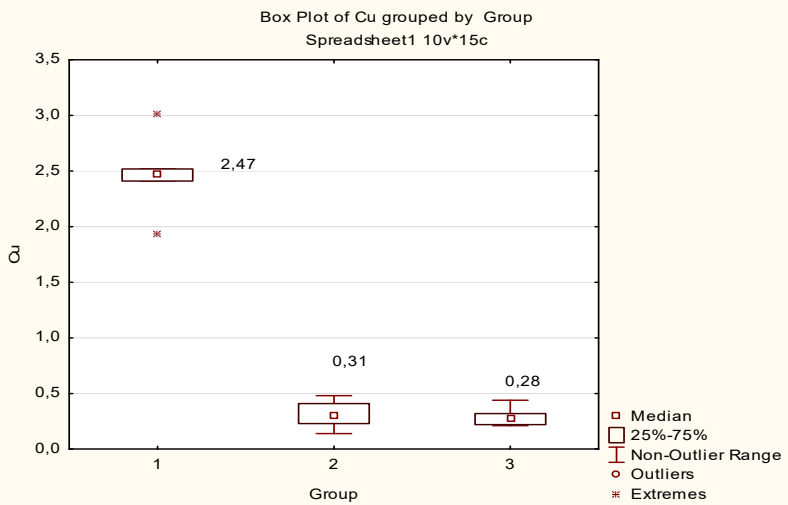

Рис. 8. Діаграма середніх значень (а) та квартільна діаграма (б) вмісту $\mathrm{Cu}$ в молоці (мг/кг) корів трьох піддослідних груп з силосно-коренеплодним типом годівлі

a

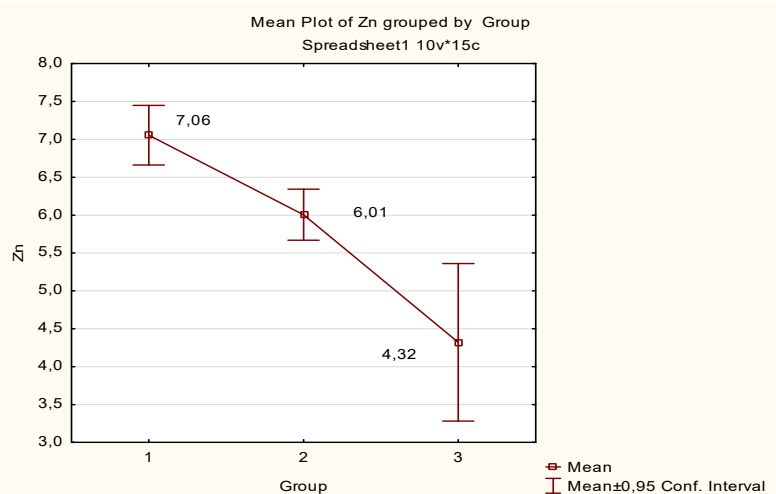

б

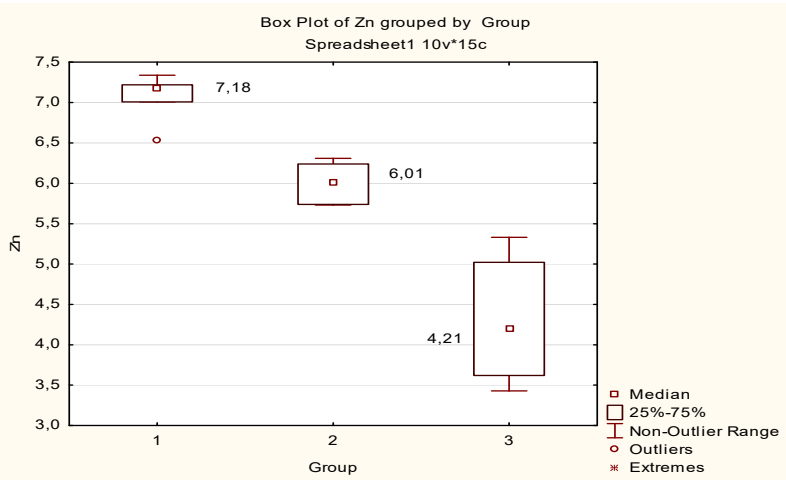

Рис. 9. Діаграма середніх значень (а) та квартільна діаграма (б) вмісту Zn в молоці (мг/кг) корів трьох піддослідних груп з силосно-коренеплодним типом годівлі 
Всі раціони були максимально збалансовані за макро- і мікроелементним складом 3 урахуванням механізму всмоктування та динаміки переміщення важких металів, зокрема кадмію і свинцю, в організмі тварин. До складу преміксів ми включили елементи антагоністи досліджуваних екотоксикантів в кількості, достатній для блокування їх всмоктування на рівні шлунково-кишкового тракту. Введення вітамінів до складу преміксу сприяло відновленню фізіологічного стану організму корів, поліпшенню роботи уражених олігодинамічною дією полютантів органів та систем. Нам вдалося досягти позитивного ефекту і знизити вміст ВМ в молоці корів в усіх господарствах за оптимальної якості, безпечності молока та продуктивності тварин. Вміст $\mathrm{Cd}$ в молоці дійних корів 3 силосносінажно-концентратним типом годівлі становив $0,053 \pm 0,019$ мг/кг у першій контрольній групі і знизився до 0,024 \pm 0,009 у другій дослідній та до 0,014 \pm 0,004 мг/кг у третій дослідній групі; $\mathrm{Pb}-31,794 \pm$ 0,165 мг/кг до $0,331 \pm 0,064$ та $0,032 \pm 0,008$ мг/кг відповідно; $\mathrm{Cu}-32,63 \pm 0,42$ мг/кг до $0,34 \pm 0,12$ та $0,35 \pm 0,17$ мг/кг відповідно; Zn $38,74 \pm 0,40$ мг/кг до $4,97 \pm 0,30$ та $3,87 \pm 0,20$ мг/кг відповідно $(\mathrm{P}<0,01)$ (табл. 1). При цьому ГДК вмісту кадмію згідно зі стандартом ДСТУ 3662-97 встановлена на рівні 0,03 мг/кг, свинцю - 0,1 мг/кг, а Регламенту (СС) № 1881/2006 на рівні 0,02 мг/кг, міді - 0,26-0,35 та цинку - 3-5 мг/кг відповідно.

Таким чином, застосовуючи комплексно премікс плюс препарат, нам вдалося суттєво знизити перехід небезпечних поютантів $\mathrm{Cd}, \mathrm{Pb}, \mathrm{Cu}, \mathrm{Zn}$ з раціону годівлі в молоко корів, при цьому посилити їхню елімінацію з організму тварин другої і третьої дослідних груп в усіх господарствах з різним типом годівлі, що підтверджує показник коефіцієнту переходу. Найбільш активна міграція $\mathrm{Pb}$ з раціону в молоко відбувалася у корів першої контрольної групи 3 силосо-сінажнокоцентратним типом годівлі: коефіцієнт переходу становив 0,39 , а по $\mathrm{Cd}-0,34$. Подібна ситуація спостерігалася і у корів перших контрольних груп з силосно-сінажним типом годівлі, де КП становив 0,36 щодо Cd та 0,34 -щодо Рb. При цьому загальне надходження ВМ з раціоном майже не відрізнялося. У тварин $з$ силосо-сінажно-концентратним типом годівлі вміст $\mathrm{Cd}$ в раціоні становив $15,77(\mathrm{~Pb}=455,64)$ мг/гол, а з силосно-сінажним - 18,95 $(\mathrm{Pb}=517,97)$ мг/гол відповідно. Найменш інтенсивна міграція $\mathrm{Cd}$ та $\mathrm{Pb}$ відбувалася у тварин першої контрольної групи, яким згодовували раціон силосно-коренеплодного типу: коефіцієнт переходу кадмію становив 0,24, а свинцю $-0,25$. Згодовування преміксу значно знизило перехід $\mathrm{Cd}, \mathrm{Pb}, \mathrm{Cu}$ та $\mathrm{Zn}$ з раціону в молоко, що показує коефіцієнт переходу, котрий у корів другої дослідної групи:

$>$ щодо $\mathrm{Cd}$ становив 0,09 у тварин 3 силоснокоренеплодним типом годівлі; 0,10 - силосносінажним; 0,12 - силосно-сінним типом та 0,15 з силосно-сінажно-концентратним типом відповідно;

$>$ щодо $\mathrm{Pb}-0,01$ у корів 3 силосно-сінажним типом годівлі; 0,07 - силосно-сінажно-концентратним; 0,08 - силосно-коренеплодним та 0,09 3 силосносінним типом відповідно; щодо $\mathrm{Cu}-0,01$ у корів 3 силосо-сінажним та силосно-коренеплодним типом годівлі; 0,02 з силосно-сінажно-концентратним та силосно-сінним типом відповідно;

$>$ щодо $\mathrm{Zn}-0,05$ у тварин 3 силосно-сінажним типом годівлі; 0,06 - силосно-сінажноконцентратним; 0,08 - силосно-коренеплодним та 0,010 з силосно-сінним типом відповідно.

У третій дослідній групі корів, де додатково застосовувалася підшкірна ін'єкція біопрепарату, в середньому коефіцієнт переходу важких металів 3 раціону в молоко щодо $\mathrm{Cd}, \mathrm{Pb}, \mathrm{Cu}$ та $\mathrm{Zn}$ становив 0,04.

Застосування преміксу та біопрепарату знизило перехід важких металів з раціону в молоко у середньому в 1,5-4,3 разу. Найбільш доцільними виявилися типи годівлі, за котрих перехід полютантів в молочну сировину був найменш інтенсивним - силоснокоренеплодний та силосно-сінажний.

\section{Обговорення}

Молоко, отримане від корів перших (контрольних) груп не відповідало вимогам екологічної безпеки згідно зі стандартом ДСТУ 3662-97. Застосування в раціонах годівлі мінерально-вітамінного преміксу "МП-А" та підшкірна ін'єкція біопрепарату "БП-9" сприяли суттєвому зниженню інтенсивності переходу важких металів $\mathrm{Cd}, \mathrm{Pb}, \mathrm{Cu}$ та $\mathrm{Zn} 3$ раціону в кінцеву продукцію - молоко. За таких умов проведення експерименту вдалося отримати найбільш екологічно безпечне молоко від корів не лише третьої, а й другої дослідної гупи 3 силосно-сінажним типом годівлі тварин при споживанні сіна люцернового 2,9 кг, сіна злаково-бобового 2,7 кг, силосу кукурудзяного 17,9 кг, сінажу люцернового 9,9 кг, дерті вівсяної 1,2 кг та горохової - 690 г. За структурою раціону на силос і сінаж припадає 60,8\%, сіно - $22 \%$, концентровані корми - 17,2\%. Вміст усіх полютантів у молоці був найменшим. У корів 3 силосно-коренеплодним типом годівлі так само екологічна безпечність молока відповідала вимогам стандарту, але лише у корів третьої дослідної групи (Р <0,01), а за вмістом міді і в корів другої дослідної групи (Р<0,01). Загалом в усіх експериментах з різними типами раціонів згодовування преміксу сприяло поліпшенню якості та екологічної безпеки виробленого молока, котре відповідало вимогам ДСТУ 3662-97 “Молоко коров'яче незбиране. Вимоги при закупівлі”, а за вмістом свинцю, мікроорганізмів та соматичних клітин стандарту (Регламентам (СС) №853/2004 та №1881/2006) країн Свропейського Союзу; збільшенню молочної продуктивності тварин (Р $<0,01)$, котра становила у середньому в корів другої і третьої дослідних груп 17-22 кг за добу порівняно 3 контрольною групою - 14 кг (Р < $0,01)$.

Піддослідні корови з силосно-коренеплодним типом годівлі споживали корми 3 найбільшим рівнем забруднення $\mathrm{Cd}$. В експерименті досягнуто стійкої тенденції посилення екскреції цього мінерального елемента $з$ сечею $(\mathrm{P}<0,01)$ зменшуючи тим самим його акумуляцію в організмі тварин та перехід у молоко. У дослідженях інших вчених використання в 
раціонах годівлі бугайців на відгодівлі силосу із злаково-бобової суміші (пелюшко-вівсяної) знижувало концентрацію свинцю та коефіцієнт його переходу в найдовший м'яз спини (продукцію), печінку та нирки (Savchenko et al., 2011).

Мінеральні елементи раціону в організмі жуйної тварини поглинаються через епітеліальні клітини, котрі встилають шлунково-кишковий тракт, щоб далі потрапити в кров для використання тканинами і в т. ч. надходження в молоко. Основна частина мінеральних елементів всмоктується у тонкому відділі кишечнику. Залежно від складу хімуса, його $\mathrm{pH}$, можуть відбуватися різні механізми всмоктування мінеральних елементів, у т. ч. і таких важливих для організму тварини в умовах інтоксикації $\mathrm{Cd}, \mathrm{Pb}$, як кальцій, фосфор, марганець, калій, кобальт, селен, сірка та ін. Один 3 таких механізмів наведено на рисунку 10.

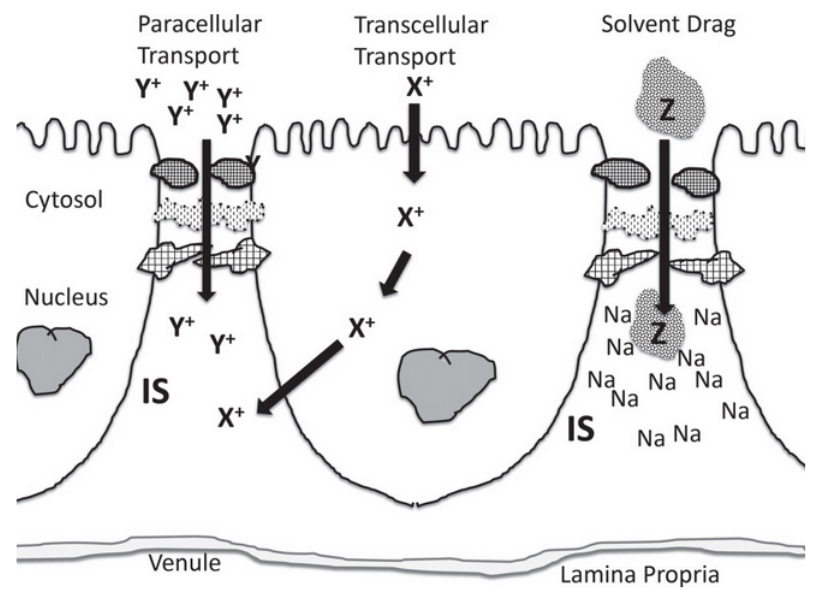

Рис. 10. Схема механізму всмоктування мінеральних елементів у ШКТ Ентероцити, котрі покривають шлунково-кишковий тракт, з'єднані один з одним за допомогою вузьких сполучнотканинних білків.

Парацелюлярне поглинання включає в себе рух іонів (позначено $\mathrm{Y}^{+}$), напрямок дифузії вниз, їх електрохімічний градієнт через пору в щільному контакті і в інтерстиціальний простір (позначено IS) через щільні з'єднання. Розчинені у воді (позначені Z) мінерали можуть переміщуватися по щільному контакту 3 об'ємним потоком води, котрий відомий як опір розчинника. Трансцелюлярне поглинання включає в себе механізми, що дозволяють мінералам (позначені $\mathrm{X}^{+}$) перейти апікальну мембрану, щоб переміщуватися по цитоплазмі клітини і для переміщення іонів через базолатеральну клітину в IS та власну пластинку для входу в судинну систему (схема механізмів за Goff, 2018).

Мінерали можуть бути нерозчинними і неіонізованими в рубці, в меншій мірі - в кишечнику, що робить ïх марними для тварини. Вченими (Goff, 2018) вивчені фактори, котрі інгібірують або сприяють розчинності мінералів. Мінерали можуть бути класифіковані як позитивно заряджені катіони та негативно заряджені аніони. Відносна кількість катіонів порівняно 3 поглинутими аніонами допомагає визначити кислотнолужний стан тварини. Деякі мінерали, такі як селен, введені нами до складу преміксу, відіграють важливу роль як кофактор антиоксидантів і допомагають зменшити окислювальний стрес, так само їх надлишок може призводити до утворення вільних радикалів, котрі, навпаки, спричиняють стрес (Goff, 2018). В експериментах на дійних коровах, котрі передбачали збагачення раціону селеном, вдавалося не лише поліпшити антиоксидантний статус тварин, а й отримати молоко 3 нижчим вмістом соматичних клітин (Séboussi et al., 2016), що підтверджується і нашими дослідженнями (Portjannyk, 2002; Mamenko \& Portjannik, 2008; Mamenko et al., 2010). Очевидно, силосно-сінажний та силосо-коренеплодний тип годівлі разом $з$ антитоксичним преміксом найкраще забезпечили функціонування тих транспортних механізмів, котрі зменшили всмоктування в кров важких металів, особливо, $\mathrm{Cd}$ та $\mathrm{Pb}$. Найменшим вміст $\mathrm{Cd}$ в крові був зафіксований у корів першої контрольної групи з силосно-сінажно-концентратним типом годівлі 77,94 нмоль/л, потім у корів з силосно-сінажним типом - 81,17 та силосно-коренеплодним 98,34 нмоль/л відповідно. Щодо $\mathrm{Pb}$ так само сислосно-сінажний тип був на другому місці 5,74 мкмоль/л. Силосно-сінажний тип годівлі за вмістом в крові $\mathrm{Cd}$ та $\mathrm{Pb}$ впевнено був на екологічно ефективним і у корів другої дослідної групи, де до основного раціону додатково згодовувався мінерально-вітамінний премікс. Інтенсивність переходу полютантів з шлунковокишкового тракту в кров зменшилася і становила щодо $\mathrm{Cd} 48,19$ нмоль/л, а щодо $\mathrm{Pb}-2,07$ мкмоль/л $(\mathrm{P}<0,01)$.

Кожна лікарська рослина, яка була введена до складу біопрепарату, володіла своїм біологічним впливом. Екстракт лимонника китайського здатний захищати печінку, нирки, селезінку, серце, легені від токсичного впливу важких металів, зменшувати негативні канцерогенні процеси в молочній залозі, пов'язані з міграцією в кров та молоко $\mathrm{Cd}$ i Pb, запобігати окисленню печінкових ліпідів; екстракт елеутерокока сприяє захисту організму тварини від шкідливого впливу важких металів, і не лише $\mathrm{Cd}$ та $\mathrm{Cu}, \mathrm{a}$ i $\mathrm{Pb}$ та $\mathrm{Zn}$, що підтвердилося нами в дослідах, активізувати інтенсивність виведення полютантів ( $\mathrm{Cd}, \mathrm{Pb}, \mathrm{Cu}, \mathrm{Zn}) 3$ крові, молока, внутрішніх органів та систем організму. Застосування цих рослинних препаратів нормалізує кров'яний тиск, виявляє імуностимулюючу дію, протистояння стресовому впливу i стимулюючий вплив на надниркові залози, що сприяло відновленню обміну мінеральних речовин в організмі. Екстракт ниркового чаю сприяв посиленню елімінації важких металів, ефективно протидіяв розвитку протеїнурії, сприяв відновленню роботи ниркових канальців та клубочкової інфільтрації в нирках, запобіг дегенеративним змінам у цьому важливому органі під час інтоксикації. Також важливим було значення в складі розробленого біопрепарату барбарису звичайного, який за масовим співвідношенням фактично зайняв 3$\epsilon$ місце - $12 \%$, що обумовлюється активними речовинами, високим вмістом вітамінів С та Е, каротину, яблучної і лимонної кислот, котрі підтримують нормальне функціонування циклу Кребса, а аскорбінова кислота, за даними (Embaby \& Afifi, 2016), є одним 3 водорозчинних антиоксидантів i виконує захисну 
функцію проти Cd-індукованих гістологічних змін в печінці, нирках, легенях, цитотоксичності для кісткового мозку. Жиророзчинний вітамін Е - один 3 найбільш важливих для інтоксикованого організму антиоксидантний фактор, що захищає тканини від окислювального стресу, виконує різні фізіологічні функції, в т. ч. акцептор вільних радикалів, запобігаючи перекисному окислюванню ліпідів, гепатопротектор печінки від біохімічних порушень, гістологічних змін в результаті впливу важких металів (Al-Attar, 2011).

Таким чином, вміст $\mathrm{Cd}, \mathrm{Pb}$ та $\mathrm{Cu}$ в раціоні силосно-сінажного типу був найменшим, перехід в молоко кадмію та свинцю - найбільшим (КП першої контрольної групи), а якість та екологічна безпечність продукції (друга і третя дослідні групи) - найкращою; в раціоні сислосно-коренеплодного типу вміст $\mathrm{Cd}$ та $\mathrm{Pb}$ в раціоні був найбільшим, перехід в молоко - найменшим (КП першої контрольної групи), якість та екологічна безпечність продукції (друга і третя дослідні групи) відповідали вимогам державного стандарту ДСТУ 3662-97, що доводить ефективність застосування в годівлі корів преміксу “МП-А" та ін'єкції біопрепарату “БП-9”. Загалом отриманий результат $\epsilon$ важливим науковим досягненням.

\section{Висновки}

Виробництво коров'ячого молока при згодовуванні кормів забруднених 3 перевищенням допустимих норм вмісту важких металів, особливо таких як $\mathrm{Cd}$ та $\mathrm{Pb}, \epsilon$ більш екологічно безпечним використання раціонів силосно-коренеплодного типу з яких відбувається менший перехід поютантів в молочну сировину. Після застосування преміксу найменшу міграцію Рb в молочну сировину мали раціони не лише сисоснокоренеплодного типу, а й силосно-сінажного та силосно-сінажно-концентратного типу, а щодо $\mathrm{Cd}$ - силосно-коренеплодного, силосно-сінажного та силосносінного типу. Додаткове згодовування тваринам спеціальних мінерально-вітамінних преміксів сприяє у 2 2,5 разу зниженню переходу токсикантів з раціону в молоко, а за сумісної ін'єкції з біопрепаратом - виробленню високоякісного екологічно безпечного молока за різних типів годівлі дійних корів.

Подальші дослідження спрямовані на підбір оптимальних типів годівлі корів та їх балансування мінерально-вітамінним преміксом, щоб забезпечити не лише зменшення переходу важких металів з раціону в молоко, а й виробництво молока з умістом полютантів в межах рівнів екологічної безпеки.

\section{References}

Al-Attar, A. (2011). Vitamin E attenuates liver injury induced by exposure to lead, mercury, cadmium and copper in albino mice. Saudi Journal of Biological Sciences, 18(4), 395-401. doi: 10.1016/j.sjbs.2011.07.004.

Bigalke, M., Ulrich, A., Rehmus, A., \& Keller, A. (2017). Accumulation of cadmium and uranium in arable soils in Switzerland. Environmental Pollution, 221, 85-93. doi: 10.1016/j.envpol.2016.11.035.
Bomko, V., Kropyvka, Yu., Bomko, L., Chernyuk, S., Kropyvka, S., \& Gutyj, B. (2018). Effect of mixed ligand complexes of Zinc, Manganese, and Cobalt on the Manganese balance in high-yielding cows during first 100-days lactation. Ukrainian Journal of Ecology, 8(1), 420-425. doi: 10.15421/2018_230 (in Ukrainian).

Bucjak, V. (2002). Transformacija vazhkyh metaliv iz kormu u moloko na tli dii ceolitu. Visnyk Sums'kogo nacional'nogo agrarnogo universytetu, 6, 585-588 (in Ukrainian).

Bucjak, V., Kravciv, R., \& Bucjak, G. (2005). Ekologichnyi monitoring vedennja tvarynnyctva $\mathrm{u}$ biohimichnyh provincijah. L'viv: Papirus (in Ukrainian).

Canty, M., Scanlon, A., Collins, D., McGrath, G., Clegg, T., Lane, E., Sheridan, M., \& More, S. (2014). Cadmium and other heavy metal concentrations in bovine kidneys in the Republic of Ireland. Science of The Total Environment, 485-486, 223-231. doi: 10.1016/j.scitotenv.2014.03.065.

Embaby, A., \& Afifi, O. (2016). Histological Study on the Protective Role of Ascorbic Acid on Cadmium Induced Cerebral Cortical Neurotoxicity in Adult Male Albino Rats. Journal of Microscopy and Ultrastructure, 4(1), 36. doi: 10.1016/j.jmau.2015.10.001.

Fischer, W., Schilter, B., Tritscher, A., \& Stadler, R. (2011). Contaminants of Milk and Dairy Products Environmental Contaminants, Encyclopedia of Dairy Sciences (Second Edition), 898-905. doi: 10.1016/B978-0-12-374407-4.00105-9.

Goff, J.P. (2018). Invited review: Mineral absorption mechanisms, mineral interactions that affect acid-base and antioxidant status, and diet considerations to improve mineral status. Journal of Dairy Science, 101(4), 2763-2813. doi: 10.3168/jds.2017-13112.

Gordijenko, O., Kostik, Ja., \& Surovceva, O. (2006). Ocinka ekologichnogo stanu gruntiv za vmistom vazhkyh metaliv. I-j Vseukrain. z'jizd ekologiv: mizhnar. nauk.-tehn. konf.: tezy dop., 247 (in Ukrainian).

Gutyj, B., Mursjka, S., Hufrij, D., Hariv, I., Levkivska, N., Nazaruk, N., Haydyuk, M., Priyma, O., Bilyk, O., \& Guta, Z. (2016). Influence of cadmium loading on the state of the antioxidant system in the organism of bulls. Biosystems Diversity, 24(1), 96-102. doi: 10.15421/011611 (in Ukrainian).

Gutyj, B., Stybel, V., Darmohray, L., Lavryshyn, Y., Turko, I., Hachak, Y., Shcherbatyy, A., Bushueva, I., Parchenko, V., Kaplaushenko, A., Krushelnytska, O. (2017). Prooxidant-antioxidant balance in the organism of bulls (young cattle) after using cadmium load. Ukrainian Journal of Ecology, 7(4), 589-596. doi: $10.15421 / 2017165$.

Gutyj, B.V., Gufriy, D.F., Binkevych, V.Y., Vasiv, R.O., Demus, N.V., Leskiv, K.Y., Binkevych, O.M., \& Pavliv, O.V. (2018). Influence of cadmium loading on glutathione system of antioxidant protection of the bullocks'bodies. Scientific Messenger of Lviv National University of Veterinary Medicine and Biotechnologies, 20(92), 34-40. doi: 10.32718/nvlvet9207. 
Hashemi, S. (2018). Heavy metal concentrations in bovine tissues (muscle, liver and kidney) and their relationship with heavy metal contents in consumed feed. Ecotoxicology and Environmental Safety, 154(15), 263-267. doi: 10.1016/j.ecoenv.2018.02.058.

Hmel'nic'kij, G., Homenko, V., \& Kanjuka, O. (1994). Veterinarna farmakologija. K.: Urozhaj (in Ukrainian).

Kulik, M., Zasuha, T., \& Velichko, I. (1995). Tradicijni i netradicijni mineraly u tvarinnyctvi. Sil'gosposvita (in Ukrainian).

Lavryshyn, Y.Y., Gutyj, B.V., Palyadichuk, O.R., \& Vishchur, V.Y. (2018). Morphological blood indices of the Bull in experimental chronic cadmium toxicosis. Scientific Messenger of Lviv National University of Veterinary Medicine and Biotechnologies, 20(88), 108-114. doi: 10.32718/nvlvet8820.

Mamenko, A., Portjannyk, S., \& Ivanov, G. (2010). Mygracyja tjazhelyh metallov $\mathrm{v}$ moloko korov $\mathrm{v}$ uslovijah zagrjaznenyja okruzhajushhej sredy polljutantamy i ksenobiotykamy. Vestnyk Ul'janovskoj gosudarstvennoj sel'skohozjajstvennoj akademyy. Nauchno-teoretycheskyj zhurnal, 2(12), 85-91 (in Russian).

Mamenko, O., \& Portjannik, S. (2008). Porushennja gomeostazu bilkiv $\mathrm{v}$ organizmi dijnih koriv pri zgodovuvanni kormiv $\mathrm{z}$ perevishhenim vmistom vazhkih metaliv. Naukovij visnik L'vivs'kogo nacional'nogo universitetu veterinarnoï medicini ta biotehnologij im. Gzhic'kogo, 10, 2(37), 222-231 (in Ukrainian).

Mamenko, O., Tatuzjan, R., Djurych, G., Jeres'ko, G., Jacjuta, M., Mishhenko, M., Kozachenko, O., Homenko, V., Jakubchak, O., Tjutjun, A., Kryzhanivs'kyj, Ja., Pabat, V., Dovgyj, A., Marchuk, L., Gurejeva, V., Babichuk, M., Marchenko, G., Ostapiv, N., \& Savchuk, G. (1997). Derzhavnyj standart Ukrai'ny 3662-97. Moloko korov'jache nezbyrane. Vymogy pry zakupivli (in Ukrainian).

Ostapyuk, A.Y., \& Gutyj, B.V. (2018). Influence of cadmium loading on morphological parameters of blood of the Laying Hens. Scientific Messenger of Lviv National University of Veterinary Medicine and Biotechnologies, 20(88), 48-52. doi: 10.32718/nvlvet8808.

Podobed, L., Candur, N., Skrylev, N., \& Nikitin, A. (1996). Tehnika sostavlenija racionov kormlenija, kormosmesej i kombikormov dlja sel'skohozjajstvennyh zhivotnyh. Odessa: OGOSHOS (in Ukrainian).

Portjannik, S. (2002). Udoskonalennja tehnologii virobnyctva ekologichno chistogo moloka $\mathrm{v}$ umovah zabrudnennja kormiv vazhkimi metalami. Problemy zooinzhenerii ta veterinarnoi medycyny. Zbirnyk naukovyh prac' Harkivs'koi derzhavnoi zooveterynarnoi akademii, 11, 317-322 (in Ukrainian).

Portjannyk, S. (2002). Vplyv premiksu i preparatu "T" na otrymannja ekologichno chystogo moloka. Visnyk Sums'kogo nacional'nogo agrarnogo universytetu. Naukovo-metodychnyj zhurnal serija "Tvarynnyctvo", 6, 471-474 (in Ukrainian).

Praice, W. (1972). Analitical atomic absortion spectrometry. London, New-York, Phein, 259-275.

Rahimi, E. (2013). Lead and cadmium concentrations in goat, cow, sheep, and buffalo milks from different regions of Iran. Food Chemistry, 136(2), 389-391. doi: 10.1016/j.foodchem.2012.09.016.

Rezza, C., Albanese, S., Ayuso, R., Lima, A., Sorvari, J., \& De Vivo, B. (2018). Geochemical and Pb isotopic characterization of soil, groundwater, human hair, and corn samples from the Domizio Flegreo and Agro Aversano area (Campania region, Italy). Journal of Geochemical Exploration, 184(B), 318-332. doi: 10.1016/j.gexplo.2017.01.007.

Roggeman, S., De Boeck, G., De Cock, H., Blust, R., \& Bervoets, L. (2014). Accumulation and detoxification of metals and arsenic in tissues of cattle (Bos taurus), and the risks for human consumption. Science of The Total Environment, 466-467(1), 175-184. doi: 10.1016/j.scitotenv.2013.07.007.

Salvatori, F., Talassi, C., Salzgeber, S., Sipinosa, H., \& Bernardi, M. (2004). Embryotoxic and long-term effects of cadmium exposure during embryogenesis in rats. Neurotoxicology and Teratology, 26(5), 673680. doi: 10.1016/j.ntt.2004.05.001.

Savchenko, Ju., \& Savchuk, I. (2013). Saponit znyzhuje koncentraciju vazhkyh metaliv u produkcii' svynarstva. Agropromyslove vyrobnyctvo, 6, 114-118 (in Ukrainian).

Savchenko, Ju., Savchuk, I., Savchenko, M., Chorna, L., Karpjuk, N. (2011). Migracija vazhkih metaliv v sistemi kormi-organizm bugajciv na vidgodivli. Visnik Zhitomirs'kogo nacional'nogo agroekologichnogo universitetu, 1(28), S. 225-231 (in Ukrainian).

Séboussi, R., Tremblay, G., Ouellet, V., Chouinard, P., Chorfi, Y., Bélanger, G., \& Charbonneau, É. (2016). Selenium-fertilized forage as a way to supplement lactating dairy cows. Journal of Dairy Science, 99(7), 5358-5369. doi: 10.3168/jds.2015-10758.

Sokolov, V., Andreeva, N., Nozdrin, G. i dr. (2002). Klinicheskaja farmakologija. M.: Kolos (in Ukrainian).

Zasekin, D. (2000). Detoksikacija nadlishku vazhkih metaliv v organizmi tvarin - zaporuka zberezhennja zdorov'ja ta oderzhannja ekologichno chistoi tvarynnyc'koi produkcii. Nauk. visn. NAU, 28, 258269 (in Ukrainian). 